\title{
Severe haemolytic anaemia after replacement of the mitral valve by a St Jude medical prosthesis
}

\author{
HARRY FELD, JAMES ROTH \\ From the Montefiore Medical Center, Albert Einstein College of Medicine, Division of Cardiology, Bronx, New \\ York, USA
}

SUMMARY Severe haemolytic anaemia developed in a 33 year old patient after the mitral valve was replaced with a St Jude medical prosthesis. This was the patient's third thoracotomy. She had already had a mitral commissurotomy and a mitral valve bioprosthesis. The patient had an $\mathrm{E}+$ antibody to red blood cells as well as a paraprosthetic leak. The haemolysis became less severe once the population of $\mathrm{E}+$ red cells was completely haemolysed. However, the patient continued to require transfusions to remain out of heart failure. Once the valve was replaced, the haemolysis subsided.

Fulminant haemolysis after mitral valve replacement is rare. When it does occur, a paraprosthetic leak should be suspected. Other causes of haemolysis, however, must also be considered and these may contribute to the severity of haemolysis.

Intravascular haemolysis after the placement of a mechanical prosthetic valve is well recognised and occurs in most patients. ${ }^{1-4}$ But increased erythropoiesis makes this common form of haemolysis not clinically significant. Fulminant haemolysis after valve replacement is rare and is usually the result of a paraprosthetic leak. We report a case of severe haemolysis after placement of a St Jude valve which was caused by a combination of red blood cell antibodies and a paraprosthetic leak.

\section{Case report}

\section{CLINICAL HISTORY AND FINDINGS}

A 33 year old black woman presented with haematuria and anaemia several days after placement of a St Jude valve in the mitral position. The patient had a history of rheumatic heart disease as a child and had mitral valve commissurotomy at age 19 . When she was 24 the mitral valve was replaced with a bovine bioprosthesis. The patient did well for nine years, then she presented with shortness of breath. Cardiac catheterisation showed an $8 \mathrm{~mm}$ end diastolic gradient. Mitral stenosis was diagnosed, and the patient underwent mitral valve replacement with a St Jude valve. Several days after the operation the patient noted the onset of haematuria. Over the next month she was admitted twice with congestive heart failure and anaemia. The patient was admitted to

Requests for reprints to Dr Harry Feld, Maimonides Medical Center, Division of Cardiology, 4802 Tenth Avenue, Brooklyn, NY 11219, USA. another hospital where she required 18 units of blood over a two week period.

\section{PHYSICAL EXAMINATION}

Upon transfer to our hospital, the patient was grossly icteric. The pulse was 90 beats/min, blood pressure $110 / 70 \mathrm{~mm} \mathrm{Hg}$, and temperature $100 \cdot 8^{\circ} \mathrm{F}$. Neck vein distension was present with normal contour. The chest was clear. The heart was hyperdynamic. There was a harsh $3 / 6$ systolic murmur and $1 / 4$ blowing diastolic murmur at the left upper sternal border. At the apex there was a blowing pansystolic murmur. There was no organomegaly or pedal oedema.

\section{LABORATORY DATA}

The urine was bloody. Microscopy did not show any red blood cells. The dipstick was $4+$ positive for haem. Urine haemosiderin was also present.

The haematocrit was $25 \%$ and a smear of peripheral blood showed schistocytes. The total serum bilirubin concentration was $42.8 \mu \mathrm{mol} / 1$, direct bilirubin was $6.8 \mu \mathrm{mol} / \mathrm{l}$, and the serum concentration of lactate dehydrogenase was $57 \cdot 2 \mu \mathrm{kat} / \mathrm{l}$. Serum haptoglobin was absent. The direct and indirect Coombs tests were negative. The manual polybrene test $^{5}$ showed two red blood cell antibodies, E+ antibodies and BGA (or HLA-7) antibodies. These were believed to be secondary to previous transfusions. Analysis of the patient's red blood cells showed that $50 \%$ of her red blood cells were $\mathrm{E}+$. The second antibody was not thought to be clinically significant or to contribute to the haemolysis. 


\section{NON-INVASIVE STUDIES}

The electrocardiogram was consistent with left atrial enlargement. The chest $x$ ray showed a large left atrium and pulmonary vascular redistribution. An echocardiogram showed a moderately enlarged left atrium of $5.2 \mathrm{~cm}$. Left ventricular size and function were normal. The aortic valve was calcified, but opened well. The mitral tilting disc prosthesis seemed grossly normal. Careful Doppler examination did not show any mitral regurgitation.

\section{CARDIAC CATHETERISATION}

The right heart catheterisation showed a right atrial pressure of $12 \mathrm{~mm} \mathrm{Hg}$, a right ventricular pressure of $75 / 14 \mathrm{~mm} \mathrm{Hg}$ and a pulmonary artery pressure of 75/ $40 \mathrm{~mm} \mathrm{Hg}$. The pulmonary capillary wedge pressure wave had an "a" wave of $25 \mathrm{~mm} \mathrm{Hg}$ and a regurgitant wave of $50 \mathrm{~mm} \mathrm{Hg}$. The left ventricular end diastolic pressure was $25 \mathrm{~mm} \mathrm{Hg}$. The cardiac output was 4.95 $\mathrm{l} / \mathrm{min}$ by thermodilution. The -left ventriculogram showed severe mitral regurgitation through an infero-posterior paraprosthetic leak. Aortography showed trace aortic insufficiency. The coronary arteries were normal.

\section{Discussion}

This patient showed several.difficulties encountered in the management of severe haemolytic anaemia after placement of a mechanical valve. Although valve dysfunction is the most likely cause of haemolysis in this type of patient, other causes may contribute and require treatment. The diagnosis of haemolysis was made in the routine fashion. A fall in haematocrit was accompanied by an increased serum concentration of lactate dehydrogenase and indirect bilirubin. Serum haptoglobin was absent. The urine appeared grossly bloody, but microscopical examination did not show any red blood cells. There was haemosiderin in the urine. Microscopical examination of the red blood cells showed schistocytes, which usually suggest mechanical trauma of red blood cells. In this case, however, the presence of schistocytes did not help determine the aetiology of the haemolysis because schistocytes are routinely found in patients with mechanical prosthetic valves. Direct and indirect Coombs tests were negative which made the diagnosis of immunohaemolytic anaemia less likely.

The Coombs test, however, can miss certain antibodies. A manual polybrene test ${ }^{5}$ was therefore performed which showed anti-E + antibodies. Analysis of the patient's red blood cells showed that $50 \%$ of her red blood cells were $\mathrm{E}+$. This indicated that a significant component of the haemolysis was $\stackrel{c}{.}$ caused by red blood cell antibodies. Therefore, in $\overrightarrow{\vec{F}}$ this patient, the only way to differentiate whether the 0 aetiology of the severe haemolysis was due to red흐 blood cell antibodies or mechanical trauma was to $\frac{\overline{\bar{c}}}{\mathrm{~s}}$ follow the patient until the $\mathrm{E}+$ red blood cells which $\stackrel{\mathrm{D}}{\mathrm{D}}$ had been transfused into this patient were lysed.

In fact the severe haemolysis in this patient was the result of the combination of red blood cell antibodies $\vec{\circ}$ and the mechanical trauma of a paraprosthetic leak. $\vec{\overrightarrow{ }}$ We followed the patient for four weeks and limited $\stackrel{\omega}{\omega}$ transfusions to when the patient's haematocrit fell below $25 \%$ and symptoms of heart failure developed. The haemolysis became less severe as the $\mathrm{E}+\operatorname{red} \mathrm{N}^{N}$ blood cells were eliminated. In the first week she needed nine units of whole blood; in the fourth week or she required only two units.

Because important haemolysis persisted despite the absence of $\mathrm{E}+$ red blood cells, a cardiac $\square$ catheterisation was performed which showed the $\mathbb{D}_{\overparen{D}}$ paravalvar leak. Then we decided to replace the valve $\frac{\mathbb{N}}{3}$ despite the high risk of a fourth thoracotomy. The haemolysis resolved immediately when the valve was replaced and there was no haematuria after ${ }_{\infty}^{\circ}$ operation. Follow up confirmed that haemolysis had. resolved, and the patient was discharged one week응 later with a stable haematocrit.

This case confirms that the most likely cause of $\frac{\bar{O}}{0}$ severe haemolysis after valve replacement is an important paraprosthetic leak. Other causes of $\underset{\complement}{\mathbb{D}}$ haemolysis can contribute to the severity of the $\overrightarrow{\vec{P}}$ haemolysis. In our case, post-transfusion antibodies $\frac{3}{3}$ were detected by the polybrene technique. One of these antibodies contributed significantly to this patient's severe haemolysis.

\section{References}

1 Kloster F. Diagnosis and management of complications 3 of prosthetic heart valves. Am J Cardiol 1975;35:0 872-85.

2 Ahmad R, Manohitharajah M, Deverell P, Watson D $\frac{D}{O}$ Chronic hemolysis following mitral valve replacement. J Thorac Cardiovasc Surg 1976;71: N 212-7.

3 Crexells C, Aerichide N, Bonny Y, Lepage G, Campeau $N$ L. Factors influencing hemolysis in valve prosthesis. Am Heart J 1972;84:161-70.

4 Rodgers B, Sabiston D. Hemolytic anemia following prosthetic valve replacement. Circulation 1969; 39-40(suppl I):I-155-61.

5 Lalezari P, Jiang A. The manual polybrene test: simple and rapid procedure for detection of red cell antibodies. Transfusion 1980;20:206-11. 